\title{
Living the Body as a New Anthropocene Experience?
}

\author{
MARTA G. TRÓgOLO \\ ALEJANDRA DE LAS MERCEDES FERnÁNDEZ \\ ROSARIO ZAPPONI \\ UNIVERSIDAD NACIONAL DEL NORDESTE [UNNE] \\ RESISTENCIA, ARgENTINA
}

ABSTRACT: In considering the performative work of the Argentinean artist, Nicola Costantino, this paper reflects on the meanings of the body as active material and conceptual support, regarding the arising of the Anthropocene. Faced with their own invention, humans engage in self-reference, which causes an estrangement and produces a given intrusion threatening the identity-integrity of the ego, inevitably resulting in repulsion. Actions performed in the process of cosmetic surgery and other scientific interventions in biological bodies manifest bodily debiscence, in the form of expulsion and negation of morphogenetic nature. Thinkers such as Lacan and Déotte are used to examine the implementation of the "body object" as a knotting of meanings, given the impossibility of reticulate substance, humanity, and subject. What remains is to witness through the body an immanent Anthropocene experience rather than one of a transcendental character, achieved in an extreme way by organic and morphological modification, particularly through surgery. This marks the result of the historical passage to techno-science as well as interpreting an Anthropocene conversion as power-totalizing. The question is whether this convergence between knowledge and practice is shaping a new experience from the experience of a completely transformed body and under what conceptions or categories the new generations will embody the Anthropocene. That concept can accommodate the treatment of a Neo-Darwinism involving the adaptation of the human species under a new form of consciousness.

KEY WORDS: natural body obsolescence, anthropo-scenic performance, intervened body, body-work

\section{THE BODY AS "SUBJECT REFERENCE"}

Beginning with the performative work of the Argentinean artist, Nicola Costantino, "Lo ominoso es el doble,"1 there arise a host of meanings of the human body as a raw material and conceptual support, related to the

\footnotetext{
${ }^{1}$ Lo ominoso y su doble" ["The ominous thing and it double"]. "Trailer," de Nicola Constantino, Fundación YPF, Puerto Madero, Buenos Aires, June/July 2010.
}

main features in what has been the rhetoric or discourses of the anthropocentric manifestation. The point of departure is the reference to the self-awareness (the real body of the artist) faced with its invention and the estrangement that is the outcome of an operation that entails unpreventable repulsion from the "body produced" by the intervening techne. Indeed it is the artist's own body, but it is uncertain whether it can be seen as her "double," as 
opposed to being another processed body whose image is a threatening intrusion into the identity-integrity of the Ego.

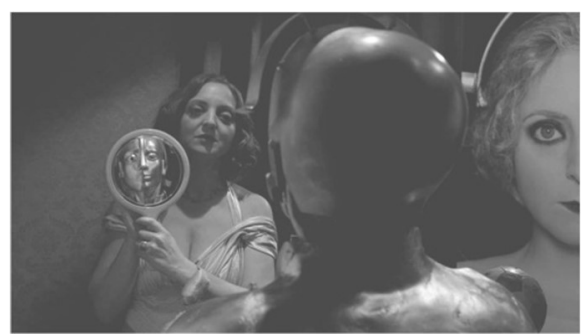

Figure 1. Image from trailer, The Ominous and Its Double.

The inquiries of the body have always been a problem, an obstacle, or at least a source of conflict, when understood with the specificity that it claims; that is, the human body that is fitted to the species and defined within it. The practices carried out in individual bodies are tellingly found in historical practices, having been conceived under categories that have often left out the common biological substratum. These gave rise to technologies that naturalized everything that was in operation on generic bodies. ${ }^{2}$ Modernity gave rise to a fulsome recovery of bodies as a visibilizing of an assigned subjectivity, made to pass from bodies differentiated by social characteristics in the political power context in terms of sexual division, and perhaps the most significant are subject bodies. Such reassigned bodies are "subject" to morphological, abstract, and conceptual objectivities.

The Sartrean dixit, "hell is other people," reverts back to the self, as condemnation of the biblical bestowal

2 Foucault, Michel. Tecnologías del yo. Paidós, 1999, pages 45-94. of freedom: you will be like God. (Gen.3: 5) The body is exposed as a stronghold and source of all human power. "Having a body" and "being a body" express only a difference of degree or intensity, but do not really bring any qualitative difference. The meaning of the expression, "having a body" reduces to "being an object," even though that is not the intended meaning, because it conveys the idea that the experience of body is inseparable from the body-object understood as the body of a person, at least as a reference. ${ }^{3}$

\section{BODY, CREATION, HISTORY}

(AS SUPERNATURAL AND

\section{TRANSHUMAN)}

The noesis of history reveals all representations as a covering of humanity with eternity. ${ }^{4}$ Nevertheless, such representation does not lie in being an inert image, but in being virtual insofar as it has produced effects on the progression of the evolution of the species. What is instrumental here is the deployment of technology, intertwined with the insertion of the experience of acceleration of time. It will be possible to hold off and resist such evolutionary acceleration, and Darwinian Theory will be put in check, along with the long-held and vituperated idea of "the natural" or "human nature" (remembering the social as second nature). The

\footnotetext{
3 Putnam, Hilary. He says: "We are not brains in a vat." Reason, Truth, and History, Cambridge University Press, 1981; reissued in: De Rose \& Warfield, Skepticism: A Contemporary Reader, Oxford UP, 1999.

${ }^{4}$ It corresponds to the hermeneutic notion of temporality according to Paul Ricoeur.
} 
explanations of natural evolution for our species are insufficient because of its location outside time. ${ }^{5}$

Biotechnological fusion is now a present reality in different areas of life; transbiological reality also crosses the conception of industry, since some of the most profitable and at the same time questionable practices are those that "produce" "organicities," autonomous or linked to similar functions of life, to recompose, compensate, improve, or recreate. The obsolescence of the content of the human, of Homo sapiens sapiens, is evidenced by the real tendency (or ability) to overcome the biological. Transbiological beings appear under the thinkable forms of the infinite, of an infinity of constitutive assemblages beyond the cyborg.

Anthropocenesis is undoubtedly a transhumanism, the content of which is given by the interactive relation between noötropics, nanotechnology, DNA genetic assembly, etc., which would enable us to consider the controversial topic of the "natural evolution of species." The real goals

\footnotetext{
5 The notion of energeia that resists movement is a metaphysical point, according to Leibniz, that differs from that of Cartesian "body" (res extensa), inert resistance.

${ }^{6}$ Kac, Eduardo. Natural History of Enigma. 2011, www.ekac.org/nat.hist.enig.html. Accessed in February 22, 2017. Eduard (o) Kac introduced a specific fragment of his DNA (extracted from chromosome 2) into a Petunia so that the plant produced "clonal" hemoglobin from himself; gave rise to an "apparatus" conceived as a new being: "Edunia." "The sculpture's form is an invented protein composed of human and plant parts. The buman part is a fragment of my Immunoglobulin (IgG) light chain (variable region). The plant component is from the Petunia's ANTHOCYANIN1 (AN1), responsible for red pigmentation in the flower. More precisely, AN1 is a
}

of the "scientific artist" are only aesthetic; they are attempts to break boundaries into the unexpected question in the field of bioethics. Was this possibility so unpredictable? Was it already in the very notion of biotechnology to be a deconstruction of an autonomous natural order whose determinism never succeeded in bridging evolutionism but in reinforcing it?

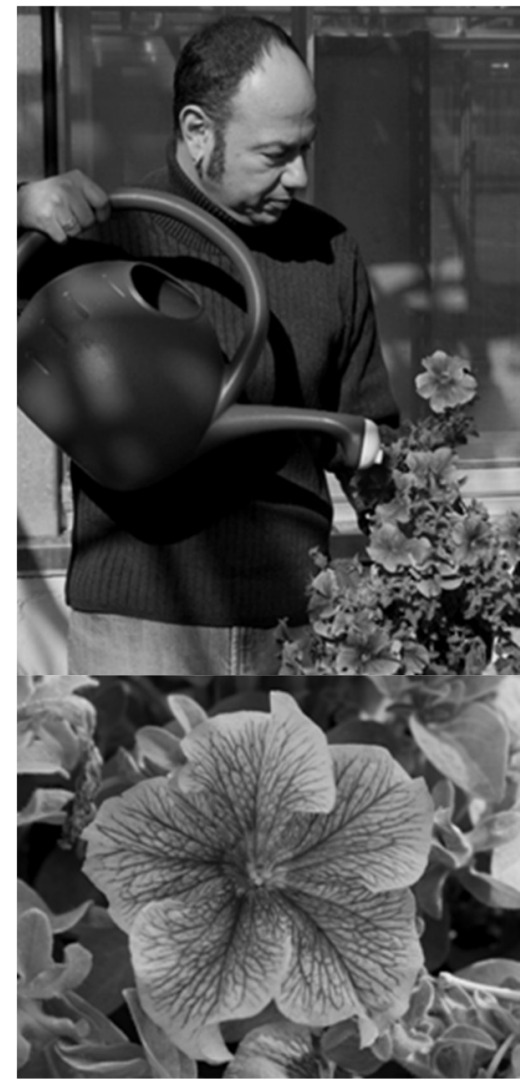

Figure 2. Eduardo Kac watering Edunia, 2009 .

transcription factor that controls genes encoding the ensymes that produce the red pigments [in blood]." The gene I selected is responsible for the identification of foreign bodies. In this work, it is precisely that which identifies and rejects the other that I integrate into the other, thus creating a new kind of self that is partially flower and partially human: me." 


\section{THE BODY AS ANTHROPOCENESIS}

It is possible to think that from within the Anthropocene matrix there arises specific interventions on bodies, whether they are "naturally" realized or mediated by extraordinary resources but accessible in some way (economic, technological, material, industrial, surgical, etc.)

The conception of nature as an independent entity is unsustainable in view of the degree of interpenetration between social and natural systems. The Anthropocene is the age of definitive confirmation of human domination over nature, including the species itself.

Man is an animal, and therefore also nature, and has evolved to a point that we are, in the words of Peter Sloterdijk, those creatures that have failed to remain animals. ${ }^{7}$ That is why technique is the interactive activity mediated as an extension that lacks biological specificity (feedback learning). The human body is a product of that creative play between biological indetermination and technological capacity for transformation. McLuhan reinterprets the history of the body "knot" and its "sensorial projections" (tetrad), along with the unavoidable changes in consciousness and the dynamic consequences that follow.

Art has always been sustained and supported in and by the body of the artist directly and indirectly, so it was possible that the same body could be a literal support of activity, taking the place of the "work," as a direct product of the poetic, actual being

7 Sloterdijk, Peter. "Regeln Für den Menschenpark." Antwortschreiben zu Heideggers Brief über den Humanismus, Frankfurt, Suhrkamp, 1999, page 34. "autopoiesis true." The bodies of artists happen to represent the same means of sense without metaphor despite the recurring fiction. However, the techniques offer mediation to allow the body to fulfill the desire, the "Holy Grail," of the demiurgic artificer. In the current conception of art there has been an obsolescence of the work as a permanent object both in its materiality and in its referentiality - and in the artist as the "outward" agent of an interior. The body voluntarily placed and "exposed" is the prolific matter to be transcended by an act that makes it strange insofar as it re-presents as another, as a double, without repeating itself. The artist transforms the art in his own experiment, disposing of his body like an obscene end of the "spectacularity" with which art always has been invested. It results also in the expectant and speculative art of the produced, and it has in this way produced the outcome of the hermeneutic circle.

\section{THE BODY AS "Mounting"}

Déotte refers to the body as a knot of (aesthetic and technical) meanings. Basically "there are no bodies"; bodies are labile results, knotted by symbolic, three-way links: of the others, of the imaginary and the strangely appropriate. Déotte's definition of the "aesthetic apparatus"8 is the con-

\footnotetext{
${ }^{8}$ Déotte, Jean-Louis. "Le Musée, un Appareil Universal,” Museum International no 235, Les enjeux de la collection au Xxi siècle, Paris, UNESCO, 2007. "Un appareil esthétique (camera obscura, perspectiv, musée, photographie, cinéma, vidéo, etc.) n'est, ni un dispositif (au sens de Michel Foucault) ni un médium de communication (au sens de Marshall McLuhan) ni une prothèse (au sens de Bernard Stiegler). L'appareil, c'est ce qui configure techniquement l'apparaître des existences, singulières ou collectives.'
} 
ceptual scheme that best expresses the fact that there are "new existences," not just new experiences. So they are not extensions, devices, or prostheses: they are genuine differential configurations. It points to a continuity of interpolation between nature and culture in such a way that innervated sensitivities (sic) ${ }^{9}$ in the body create contemporaneity among individuals. If the body is the knot that happens between the real, the imaginary and the strange, ${ }^{10}$ that is to say what is never given to us, then what follows is the impossibility of feeling it as substance, humanity, subject, etc. What remains is to witness through the body an anthropocentric experience anew, that of the era that geologists and geographers have defined as the era of global change by the predominant intervention of human forces resulting in the end of the Holocene. ${ }^{11}$

All technology and in particular biotechnology is already inserted in the everyday conditions that make life possible under new forms (in extension, in exchange, and in creation). Consequently the possibilities of experiences promise to be inexhaustible prima facie. The inherent nature of modeled forms marks the historical passage of nature as a "model" toward techno-science as totalizing power. Actions per-formed

9 Déotte, Jean-Louis. L'homme de Verre: Esthétiques Benjaminiennes. Editions L'Harmattan, 1997.

10 His reference has been taken from Lacan's scheme on the body.

11 British Geological Survey and AWG. This change implies a new scenario in the which would be anachronistic to speak of man, world, life, maintaining the same contents and the same relationships that we have used so far. under an artificial morpho-genesis, including the insertion of specific DNA fragments and surgical aesthetics, manifest the dehiscence of the existing corporeal matter as expulsion and denial of this nature.

The body cannot continue to be spoken of as a biological support predetermined by inheritance in the sense of itself and the species. The non-transcendental feature of immanence is viewed in an extreme way by organic and morphological modification through surgeries and modifications induced in the DNA of any known form of life.

As ending overview: We consider whether it would be possible to speak of McLuhan-style Neo-Darwinism as referring to the notion of the adaptation of organisms along new configurations of consciousness.

\section{BODY REFUGE AND RESISTANCE: THE WORK OF NICOLA COSTANTINO}

Costantino's work is an emergent work of the flesh, an evolution from the experiences of the images of the living world to her own body as an experimental support. The work that we refer to almost exclusively is the creation of the remarkable film "La Artefacta," 12 in which the artist can be seen to bring contradictions and specularities into play concerning art and the most organic aesthetic experience: body of self, experiencing its own boundaries. Cutting and

12 "La Artefacta" ["The Artefacta"], created by filmmaker Natalie Cristiani to exhibit at the 55th International Art of the Venice Biennale, 2015, nicolacostantino.com.ar/artefacta-trailer.php. Based on Argentina`s work "Rapsodia inconclusa" [Unfinished Rhapsody] in the 54th International of Venice Biennale, 2013. castagninomacro.org/page/exposiciones/id/1 58/title/Rapsodia-Inconclusa. 
inspecting the body and its folds and "sleeves" are the conscious forms that the artist adopted to allude to the exposure and fragility of the body, in particular the woman's body; the main character is a woman - a psychoanalytic translation of his father surgeon and his mother dressmaker.

In her first experiences close to the performances, the artist sets out to recreate the mythical procedure of sparagmosis (dismemberment), a ritual by which all notion of separateness was lost and only flesh in its various forms reigned: flesh of the victim (food), meat of pleasure (of sensory enjoyment) and the flesh of the suffering, looking. The meaning of the materiality of bodies is related to motherhood in the sense of the capacity to receive, in an abstract sense of the container, that which can shelter or contain another. The edge that the artist decides to put in her work/body (undifferentiated) arises when something happens that alters her "normal body" and is not in principle subject to her will in relation to her form: a pregnancy. "More than having a previous space where you put bodies inside, it is the bodies that make the place, the background reflection has to see what the idea of giving and making place means."13 The new being (expression par excellence of the touching-you $)^{14}$ is a kind of device of Déotte's in which he posits differentiation and at the same time establishes a dependence

13 Derrida, J. El Tocar, Jean-Luc Nancy. Translated by Irene Agoff, Amorrortu, Bs.As., 2011, pages 399-401.

14 "Se toucher-toi," original expression of JeanLuc Nancy to signified "touch by self as other self." on certain extrinsic conditions to live. Likewise, a strange event occurs: a spectator from within, who becomes hostile while "lodged" in the uterus and grows according to an extreme intrinsic determinism, that of the human genome with its own DNA. "The strength and presence of the artist is felt, even at a distance," but there is no audience that can complete this peculiar performance save for the fetal "apparatus" itself” (extraorganic). We would think of the intrusion of the other into itself, as trans-organicity from one to-itself into another to-itself: a strange being, differentiated by its DNA, and yet reconnected to substantiate itself in the reciprocal body-matrix.

Who is an artifact? Is it she Constantine - herself? Is it her apparatus that was bordering on constituting a metaphor of transformation in itself, as an oversized expression of transcendence in her own determination? Apparatus is an image and likeness of itself, but strangely "outside." The bodies can be touched, both by oneself and by others (partage by Nancy) because the border ambiguity "overflows" every concept and also including the experience of the touch. But in Constantine's work, touch is nevertheless the most distant: forms are far removed from touch, repulsive in terms of tactile sensations, but the gaze traverses them under forms of touch.

The ambiguous bodies, overwhelmed and tactile, depart from Kant's anachronistic imperative to consider man always as an end, never as a means. Nowadays, imposing a phenomedia biotechno-anthropocene makes possible the transformation of 
man into a virtual reality of being, a possibility between multiple, almost inexhaustible power to be and become.

The end and media made indiscernible virtual and material possibilities of technology have reduced the telos to the present, closing the expectation of future. The time is reduced instantly to "right now."15

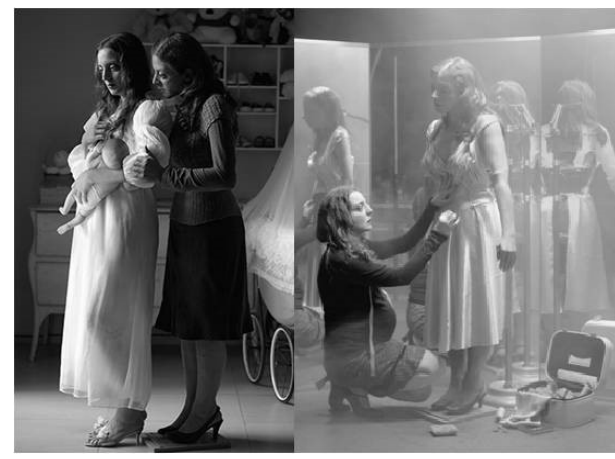

Figure 3. Images from The Ominous Thing and Its Double.

\section{CONCLUSIONS}

According to psychologist Kenneth Ring, author of The Omega Project, the transformation of Anthropocenesis "leads us toward a fundamental reorientation of our personal world of values and visions but it is more important that they also seem to accelerate a psychophysical transformation."

However it is probably to break through the threshold of ordinary consciousness to access "transpersonal dimensions" that a new, "more advanced" species is emerging, according to the anachronism of the paradox in

15 This idea means "Ecstasy," according to Augustinian phenomenological concept of consciousness and temporality. current academic discourses. Perhaps a "different species" is in play here, whose limits are no longer biological, for the creative imagination has given rise to a transmaterial, transorganic, unstoppable, and synergistic direction of changes sustained in forms of transcendence operated here on Earth, the body no longer without it. The living body is no longer alive in virtue of the biological processes fixed in the alleles originating from the species, but by the intrinsic capacity of having developed in ontogenesis a total capacity to induce arbitrary changes above all purpose and necessity, to own the joy to do, to enjoy, to be another.

When Danto says "the world does not deserve the beauty," he appeals to the sustenance of the human as historically understood to construct that which supposes the beautiful as its teleological correlate. ${ }^{16}$ In Plato, however, beauty was identified with truth, immutable and eternal. Could it be actually this eternity situated as the matter of life itself, signified by a biotechnology that intervenes directly in anabolism and cellular catabolism, that is, in the mitochondrial center itself of non-aging, of non-mortality? Are we forming a new anthropocentric experience based on the experience of a totally transformed body? Under what topics will the new generations realize it and for whom?

And in this context, is art the reflexive moment "about" aesthetics, a need for separateness leading to oblique consciousness? It is what has been saving us from extinction since

16 Danto, Arthur. El abuso de la belleza. La Estética y el concepto de Arte. Translate by Carles Roche, Paidós, 2008. 
the Neanderthal was subsumed by Homo sapiens, although its DNA is still embedded in ours, a consciousness that reflects and pauses, but only to metamorphose. This is the reverse intention of Kafka's reference to the deplorable and abandoned. The monster, the ominous, is the desired thing, never reached. The Anthropocene belongs to an almost undivided totality, where sensory synergy translates into experience on the body; technology is the objectification of this possibility more real than material. If the body is the medium, and the medium is message, then what is the end of the intervened body? It may even be death contempt or indifference to and for life - although paradoxically the cultural call to live a healthy life to prolong it, and death is worthy, even appealing, to Euthanasia.

\section{WORKS CITED}

Danto, Arthur. "El Abuso de la Belleza. La Estética y el Concepto de Arte. Trans. Carles Roche. Barcelona: Paidós, 2008.

Déotte, Jean Louis. "Le Musée, un Appareil Universal." Museum International No 235. Paris: UNESCO, 2007.

Déotte, Jean Louis. "L'homme de Verre: Esthétiques Benjaminiennes.”
París: L'Harmattan, 1995.

Derrida, Jacques. "El tocar, Jean-Luc Nancy." Trans. Irene Agoff . Buenos Aires: Amorrortu, 2011. 399-401.

Foucault, Michel. "Tecnologías del yo." Trans. Mercedes Allendesalazar. Buenos Aires: Paidós, 2008. 45-94.

Kac, Eduardo. "Re: Natural History of Enigma." Online posting. 22, Feb. 2011, www.ekac.org/nat.hist.enig. html.

The Artefacta. Prod. Chiapetta, Francesca and Cristiani, Natalie. Dir. Cristiani, Natalie. Film. Venice Film Festival, 2015.

Trailer. Prod. Nicola Costantino. Dir. Nicola Costantino and Victor Kesselman. Film. Puerto Madero, 2010.

Putman, Hilary. Reason, Truth, and History, United Kingdom: Cambridge University Press, 1981.

Sloterdijk, Peter. Regeln für den Menschenpark. Antwortschreiben zu Heideggers Brief über den Humanismus. Frankfurt: Suhrkamp, 1999, 34. 